\title{
Arahan Peningkatan Daya Tarik Pariwisata Di Kawasan Pecinan Kota Lama Kembang Jepun Surabaya
}

\author{
Muhammad Luthfi Amrullah dan Arwi Yudhi Koswara \\ Departemen Perencanaan Wilayah dan Kota, Institut Teknologi Sepuluh Nopember (ITS) \\ e-mail:arwi_yudhi@urplan.its.ac.id
}

\begin{abstract}
Abstrak-Bagian Kota Surabaya ini masih dipertahankan dari sisi bangunan yang harus dilestarikan telah disusun peraturannya yaitu Peraturan Daerah Kota Surabaya No. 5 Tahun 2005 tentang Pelestarian Bangunan dan atau Lingkungan Cagar Budaya. Menurut Rencana Detail Tata Ruang Kota (RDTRK) UP Tanjung Perak Surabaya 20112031, kawasan Kembang Jepun diarahkan sebagai wilayah perencanaan bangunan cagar budaya Pecinan golongan $\mathrm{C}$, dilaksanakan sesuai ketentuan Perda No. 5 tahun 2005 Bab IV Pasal 16 melalui Revitalisasi atau Adaptasi, dengan pengembangan zona wisata kuliner dan wisata sejarah, budaya, dan arsitektural. Berdasarkan peraturan yang sudah berlaku dan ditetapkan masih belum terlaksana sepenuhnya. Fungsi kawasan cagar budaya yang ditetapkan dikawasan pecinan Kota Surabaya masih butuh penambahan atau revitalisasi dari segi infarstruktur maupun bangunan tua yang merupakan aset Kota Surabaya. Perlu arahan untuk meningkatkan nilai kawasan tersebut karena adanya potensi pariwisata yang masih belum dimanfaatkan sepenuhnya.dari kondisi diatas diperlukan arahan untuk meningkatkan daya tarik pariwisata kawasan tersebut. Untuk mendapatkan arahan tersebut diperlukan tahapan sebagai berikut (1) Mengidentifikasi karakteristik Kawasan Pecinan berdasarkan potensi kawasan tersebut menggunakan analisis deskriptif. (2) Menentukan Faktor peningkat daya tarik pariwisata ke Kawasan Pecinan menggunakan metode analisis delphi. (3)merumuskan Arahan peningkatan daya tarik pariwisata kawasan pecinan kembang jepun Kota Surabaya menggunakan analisis deskriptif. Penelitian ini menghasilkan dari penelitian ini adalah arahan pada setiap faktornya, seperti revitalisasi bangunan heritage, pelestarian budaya khas kawasan pecinan yang bisa dilaksanakan melalui acara tahunan, dan kebetuhan akan kelembagaan yang mengelola kawasan pecinan secara terpadu.
\end{abstract}

Kata Kunci-Delphi, Revitalisasi, Cagar Budaya, Pariwisata, Daya Tarik.

\section{PENDAHULUAN}

K awasan central business district yang masih bertahan dari jaman kolonial hingga sekarang, salah satunya yaitu kawasan Pecinan Kota Lama Surabaya. Bagian Kota Surabaya ini masih dipertahankan dari sisi bangunan yang harus dilestarikan telah disusun peraturannya yaitu Peraturan Daerah Kota Surabaya No. 5 Tahun 2005 tentang Pelestarian Bangunan dan atau Lingkungan Cagar Budaya adalah tentang umur, keaslian, nilai sejarah, kelangkaan, dan ilmu pengetahuan. Sedangkan apabila dilihat dari kondisi eksisting kawasan Kota Lama Surabaya pengelolaan dari segi cagar budaya masih belum optimal.

Menurut Rencana Detail Tata Ruang Kota (RDTRK) UP Tanjung Perak Surabaya 2011-2031, kawasan Kembang Jepun diarahkan sebagai wilayah perencanaan bangunan cagar budaya Pecinan golongan C , dilaksanakan sesuai ketentuan Perda No. 5 tahun 2005 Bab IV Pasal 16 melalui Revitalisasi atau Adaptasi, dengan pengembangan zona wisata kuliner dan wisata sejarah, budaya, dan arsitektural Lalu diatur juga dalam Dalam Perda No. 5 tahun 2005 Bab IV Pasal 16 tentang konservasi bangunan cagar budaya Golongan $\mathrm{C}$ dilaksanakan dengan ketentuan perubahan bangunan dapat dilakukan dengan syarat tetap mempertahankan tampang bangunan utama termasuk warna, detail dan ornamennya lalu didalam penambahan bangunan di dalam tapak atau persil hanya dapat dilakukan di belakang bangunan cagar budaya dan harus disesuaikan dengan arsitektur bangunan cagar budaya dalam keserasian tatanan tapak dan fungsi bangunan dapat diubah sesuai dengan rencana kota [1][2].

Belum optimalnya pengelolaan dan pelestarian benda dan bangunan serta kawasan cagar budaya merupakan sebuah faktor penghambat dalam pengembangan destinasi wisata di Surabaya berdasarkan dokumen Rencana Strategis (RENSTRA) Dinas Kebudayaan dan Pariwisata (DISBUDPAR) Kota Surabaya 2016-2021 oleh karena itu melalui misi "mengembangkan potensi pariwisata yang ada di Kota Surabaya secara optimal" untuk mencapai tujuan tersebut juga dirumuskan sasaran Dinas Kebudayaan dan Parwisata Kota Surabaya salah satunya "melindungi bangunan Cagar Budaya" [3].

Perkembangan kawasan Kota Lama Surabaya terutama dikawasan pecinan kini perlahan hanya terisi disiang hari berupa aktivitas perdagangan sedangkan dimalam hari tidak adanya aktivitas yang berlangsung [4]. Selain itu masih adanya permasalahan di kawasan pecinan yang seharusnya di Kawasan tersebut dapat diperhatikan lebih baik karena sudah masuk didalam beberapa dokumen rencana dan peraturan. Integrasi Kawasan yang seharusnya bisa dijangkau dengan berjalan kaki namun kenyataanya fungsi pedestrian ways tidak sesuai fungsi searusnya terutama di Koridor Kawasan Pecinan.

Ketidaksesuaian dengan pengoptimalan kawasan cagar budaya yang mengakibatkan tidak tercapainya rencana yang diinginkan oleh pemerintah. Potensi tersebut malah dimanfaatkan salah satu organisasi yang peduli dengan historical yang perlu dikembangkan ke arah wisata agar semua dapat menikmati dan mengingat kembali Surabaya seperti sedia kala. Seharusya potensi tersebut dapat dimanfaatkan dan perlu dilakukan penelitian guna untuk meningkatkan daya tarik wisata di Kawasan Pecinan Surabaya.

Berdasarkan peraturan yang sudah berlaku dan ditetapkan masih belum terlaksana sepenuhnya. Fungsi kawasan cagar budaya yang ditetapkan dikawasan pecinan Kota Surabaya masih butuh penambahan atau revitalisasi dari segi 
Tabel 1.

Hasil Sintesa Pustaka

\begin{tabular}{cc}
\hline \hline Indikator Peningkat DTW & Variabel \\
\hline Bangunan & Gapura \\
& $\begin{array}{c}\text { Bangunan Bersejarah } \\
\text { Tempat Sembayang/ Klenteng }\end{array}$ \\
\hline \multirow{2}{*}{ Event } & Kebudayaan perayaan imlek \\
& Festival \\
\hline \multirow{2}{*}{ Aksesibilitas } & Jaringan jalan \\
& Moda Transportasi (umum) \\
& Rute \\
\hline \multirow{3}{*}{ Ketersediaan Prasarana Pendukung } & Pedestrian \\
& Lahan Parkir \\
& Landmark \\
& Rambu - rambu \\
& Pusat Oleh-oleh \\
\hline \multirow{2}{*}{ Ekonomi } & Kuliner \\
& Peluang bagi masyrakat lokal \\
\hline \hline
\end{tabular}

infarstruktur maupun bangunan tua yang merupakan aset Kota Surabaya. Perlu faktor penarik untuk meningkatkan nilai kawasan tersebut karena adanya potensi pariwisata yang masih belum dimanfaatkan sepenuhnya.

Berdasarkan hal tersebut, studi ini dilakukan untuk mencari strategi sebagai upaya untuk meningkatkan daya tarik wisata kawasan pecinan kembang jepun Kota Surabaya. Sehingga pertanyaan penelitian ini adalah "Bagaimana cara meningkatkan daya tarik pariwisata dikawasan pecinan yangmerupakan kawasan heritage kawasan kota lama di Surabaya?"

\section{METODE PENELITIAN}

Untuk menentukan arahan peningkat daya tarik pariwisata kawasan pecinan Kembang Jepun kota Surabaya, perlu dilakukan 3 tahapan penelitian yaitu Mengidentifikasi karakteristik Kawasan Pecinan berdasarkan potensi kawasan tersebut, dan Menentukan Faktor peningkat daya tarik pariwisata ke Kawasan Pecinan. Luaran penelitian ini berupa arahan peningkatan daya tarik pariwisata kawasan pecinan kembag jepun Kota Surabaya. Pengumpulan data primer dilakukan dengan kuisioner serta wawancara. Sedangkan data sekunder diperoleh melalui berbagai tinjauan literatur atau data instansi. Pengumpulan data sekunder ini oleh peneliti disentesakan serta dijadikan sebagai teori penelitian.

\section{A. Mengidentifikasi karakteristik Kawasan Pecinan berdasarkan potensi kawasan tersebut.}

Untuk mengidentifikasi karakteristik kawasan Analisis yang digunakan dalam mengeksplorasi dan mengidentifikasi karakteristik kawasan adalah metode analisis deskriptif kualitatif dimana akan ditampilkan fakta, keadaan dan fenomena yang terjadi ketika penelitian berlangsung dan menyajikan apa adanya sesuai tahapan tahapan apa saja yang harus di penuhi. Tahapan yang harus dilakukan adalah dengan membuat daftar variabel yang akan diamati. Daftar tersebut didapatkan melalui proses sintesa kajian pustaka. Selanjutnya dilakukan observasi atau pengamatan langsung pada wilayah penelitian. Hasil dari analisis untuk mengetahui bagaimana karakteristik kawasan pecinan.
Tabel 2.

Hasil kuisioner Delphi iterasi kedua (Konsensus)

\begin{tabular}{cc}
\hline \hline Indikator Penngkat DTW & Variabel \\
\hline Bangunan & Gapura \\
& Bangunan Bersejarah \\
Tempat Sembayang/ Klenteng
\end{tabular}

B. Menentukan faktor - faktor yang meningkatkan daya tarik pariwisata di Kawasan Pecinan Kembang Jepun Surabaya

Untuk menentukan faktor-faktor yang meningkatkan daya tarik pariwisata kawasan pecinan Kembang Jepun Kota Surabaya dilakukan analisa Delphi yang menggabungkan beberapa pendapat dari stakeholder untuk ditarik kesimpulan. Adapun beberapa tahapan yang Penggunaan analisis Delphi sendiri sebagai proses komunikasi kelompok para ahli yang bertujuan melakukan pemeriksaan secara rinci dan diskusi terhadap perkembangan perumahan di Kecamatan Sukodono yang bertujuan untuk menemukan faktor - faktor yang berpengaruh terhadap perkembangan perumahan disana. Teknik analisis Delphi merupakan metode yang digunakan secara luas dan diterima untuk mencapai konvergensi pendapat mengenai pengetahuan dunia nyata yang diminta dari para ahli pada bidang tertentu [5].

Untuk mengidentifikasi stakeholders yang akan diambil sebagai responden penelitian, akan digunakan analisis purposive sampling. Analisis ini dilakukan dengan menentukan kriteria - kriteria stakeholders yang dapat membantu menjawab kuisioner penelitian ini. Sehingga di dapatkan stakeholders tersebut, yaitu :

1. BAPPEKO SURABAYA.

2. Dinas Kebudayaan dan Parwisata Kota Surabaya

3. Akademisis Perencanaan Wilayah dan Kota.

4. Komunitas.

Setiap responden akan diberikan kuisioner mengenai faktor - faktor yang meningkatkan daya tarik wisata melalui 14 variabel yaitu, bangunan bersejarah, gapura, Klenteng, kebudayaan perayaan imlek, Festival, jaringan jalan, moda transportasi, rute wisata, pedestrian, lahan parkir, landmark , kuliner dan peluang bag masyrakat local. Pada kuisioner, responden akan diberikan pertanyaan apakah variabel variabel tersebut memiliki pengaruh atau tidak pada peningkatan daya tarik pariwisata kawasam pecinan kembang jepun Kota Surabaya serta alasan dari setiap jawaban tersebut. 


\section{Merumuskan arahan peningkatan daya tarik wisata di kawasan pecinan Kembang Jepun Kota Surabaya}

Tahap analisis terakhir dalam penelitian ini adalah merumuskan arahan penigkatan daya tarik pariwisata kawasan pecinan kota lama Surabaya. Penelitian ini mengunakan analisis deskriptif, yang langkah pertama menggabungkan faktor yang sudah disepakati disasaran kedua yaitu faktor penigkat daya tarik dan kondisi eksisting yang sudah diidentifikasi pada sasaran pertama. Langkah terakhir menggunakan best practice dikomparasikan untuk merumuskan arahan agar lebih spesifik. Berikut adalah tabel arahan peningkatan daya tarik wisata di kawasan pecinan kawasan kota lama Surabaya.

\section{HASIL DAN DISKUSI}

\section{A. Mengidentifikasi karakteristik Kawasan Pecinan berdasarkan potensi kawasan tersebut.}

Didalam analisis ini didapatkan melalui proses sintesa kajian pustaka. Selanjutnya dilakukan observasi atau pengamatan langsung pada wilayah penelitian dan dilakukan juga pertanyaan terkait tiap variabel kepada stakeholders. Hasil dari analisis untuk mengetahui bagaimana karakteristik kawasan pecinan. Untuk lebih mendalam dapat dilihat pada Tabel 1.

\section{1) Gapura}

Gapura yang kondisinya baik sebagai salah satu landmark kawasan pecinan.baik bentuk gapura kya kya yang sangat mewakilkan kawasan pecinan Kota Surabaya dengan gaya arsitektur orientalnya.

\section{2) Bangunan Bersejarah}

Banyaknya bangunan yang masih minim informasi asal usulnya, beberapa bangunan kondisinya terbengkalai. Lalu hasil analisis dilihat dari dokumen masih belum optimal dari seharusnya dalam rencana dlakukannya perlindungan bangunan heritage guna memepertahankan nlai kawasan pecinan itu sendiri.

Pengetahuan masih minim karena tidak adanya deskripsi tiap bangunan cagar budaya yang pasti untuk masyarakat juga dapat ikut melestarikannya

\section{3) Tempat Sembahyang (klenteng)}

Klenteng yang usia bangunan yang sudah sangat tua masih terjaga dengan baik kondisinya. Pengunjung klenteng pun masih banyak tidak hanya wisatwan dalam begeri juga ada wisatwan. Dari hasil analisis dilihat dari kondisinya masih baik namun kondisi sekitar klenteng yang masih belum melambangkan kawasan pecinan.

\section{4) Kebudayaan perayaan imlek}

Perayaan imlek dari tahun ketahun yang biasanya diadakan dikoridor jalan kembang jepun dalam beberapa tahun terakhir sudah tidak diadakan. Sedangkan perayaan imlek sendiri berpusat di dua klenteng yang berada dikawasan pecinan. Dari hasil analisis perlu adanya Kebudayaan imlek merupakan ciri khas kawasan pecinan yang searusnya pemerintah bisa memanfaatkan untuk pengembangan kawasan pecinan. Lalu masih belum adanya event yang melambangkan kawasan pecinan selain event perayaan imlek

\section{5) Festival}

Sudah ada beberapa event yang digelar secara tahunan seperti festival "rujak uleg" dikoridor kembang jepun. Merupakan festival yang ditunggu masyarakat terlihat dari kehadiran cukup tinggi diacara tersebut. Dari hasil analisis perlu adanya pengembangan kawasan kawasan pecinan yang berada di Kota Lama melalui event ini sangatlah membantu sebagai salah satu daya tarik kawasan untuk memperlihatkan bahwa Kota Surabaya memiliki Kawasan Pecinan. Namun masih kurangnya identitas kawasan pecinan yang dimunculkan.

\section{6) Jaringan jalan}

Jaringan jalan di kawasan pecinan berpola sirkulasi satu arah, kemacetan masih ada dibeberapa titik dikarenakan bongkarmuatan perdagangan dan jasa yang di pinggir jalan. Dari hasil analisis Pola sirkulasi yang satu arah mengakibatkan apabila wisatawan ingin berpinda tempat arus memutar arah lebih jauh apabila menggunakan kendaraan bermotor. Selain itu system bongkar muat didaerah tersebut masih tidak tertata dimana bongkar muat dilakukan dipinggir jalan yang mengakibatkan kemacetan.

7) Moda Transportasi Umum

Pilihan moda angkutan transportasi terbatas, tidak meyeluruh ke seluruh kawasan pecinan. Dari asl analisis Pilihan angkutan yang minin mengakibatkan tidak terjamah seluruhnya selain fungsi perdagangan dan jasa yang masih tidak teratur apabila melukakn bongkar muat yang mengakibatan kemacetan lalu sirkulasi jalan yang satu arah mengakibatkan wisatawan sulit menjangkau objek wisata.

\section{8) Rute}

Belum adanya rute dan penanda objek wisata di kawasan pecinan. Lalu didapatkan hasl analisis bahwa Kebutuhan akan rute dan penjelasan berupa deskripsi kawasan juga perlu adanya untuk membantu wisatawan yang berkunjung mencapai objek wisata yang ingin dituju

\section{9) Jalur Pejalan Kaki}

Masih belum menyeluruh jalur pejalan kaki, ketersediaan jalur pejalan kaki yang optimal adanya dikoridor jalan kembang jepun untuk jalan lainnya masih dalam tahap pengembangan. Dari hasil analisis didapati bahwa Jalur pejalan kaki merupakan faktor yang penting dikarenakan penghubung yang paling tepat antar objek wisata dikawasan pecinan. Jalur pejalan kak yang sudah ada fungsinya pun masih belum optimal dikarenakan pemanfaatan lahan parkir, berjualan pedagang kaki lima dan melubernya dagangan di tiap rukonya.

\section{0) Lahan Parkir}

Ketersediaan lahan parkir ditiap ruas jalan ada dengan sistem pembeda yaitu parkiran untuk bongkar muat barang dan parkir untuk kendaraan umum. Dari hasil analisis didapati bahwa untuk parkiran yang berada di jalan waspada dan jalan bongkaran masih tertata rapi namun untuk beberapa ruas lain perparkirannya masih tidak sistematis yang mengakibatkan kemacetan.

\section{1) Landmark rambu-rambu dan pusat oleh-oleh}

Kurangnya rambu-rambu atau penanda landmark objek wisata, tidak adanya pusat oleh oleh yang menjual oleh oleh khas kawasan pecinan.. Apabila penetapan kawasan Kota Lama terutama pecinan sebagai kawasan heritage seharusnya pengembangan dilakukan secara optimal untuk meningkatkan daya tarik wisata ke kawasan pecinan memalui branding kawasan yang lebih optimal dengan ke khasan kawasan tersebut.

\section{2) Kuliner khas kawasan pecinan}

Kuliner untuk siang hari masih minim pilihan. Namun apabila malam ari banyaknya pilihan dikarenakan kebanyakan penjual buka di malam hari. Dari hasil analisis didapati bahwa pilihan kuliner khas kawasan pecinan masih sedikit. Mayoritas pilihan kuliner khas pecianan masih 
Tabel 3.

Arahan Peningkat Daya Tarik Pariwisata Pecinan

\begin{tabular}{|c|c|c|}
\hline No. & Variabel & Arahan \\
\hline 1. & Gapura & Penambahan landmark kawasan pecinan agar terlihat dmana batas kawasan dan ciri khas kawasan pecinan \\
\hline \multirow[t]{2}{*}{2.} & Bangunan Bersejarah & Pengelolaan kawasan yang terpadu terhadap bangunan heritage, bentuknya berupa revitalisasi bangunan heritage. \\
\hline & & $\begin{array}{l}\text { Perlu adanya daftar bangunan yang termasuk dalam bangunan heritage agar dapat dilestarikan keberadaannya karena } \\
\text { sebagai salah satu peningkat citra kawasan pecinan yang sudah luntur adanya. }\end{array}$ \\
\hline 3. & $\begin{array}{l}\text { Tempat sembahyang/ } \\
\text { klenteng }\end{array}$ & $\begin{array}{l}\text { Optimalisasi kawasan sekitar dengan ornament khas seperti patung, warna bangunan yang menandakan ciri khas } \\
\text { menjadi objek wisata yang khas dari kawasan pecinan }\end{array}$ \\
\hline 4. & $\begin{array}{l}\text { Kebudayaan/ perayaan } \\
\text { imlek }\end{array}$ & $\begin{array}{l}\text { Pelestarian budaya perayaan imlek yang perlu dilestarikan tradisinya sebagai salah satu penarik wisatawan dan } \\
\text { bentuk toleransi antar umat beragama yang tentunya perayaan ini perlu diadakan ditiap tahun. }\end{array}$ \\
\hline \multirow[t]{2}{*}{5.} & festival & $\begin{array}{l}\text { Event yang diadakan sebagai bentuk branding kawasan, perlu eksplorasi event yang memunculkan ciri khas kawasan } \\
\text { pecinan yang selama ini branding dalam bentuk event masih kurang adanya.. }\end{array}$ \\
\hline & & Menggandeng komunitas etns tiongoa sebagai salah satu peyelenggara event. \\
\hline 6. & Jaringan jalan & $\begin{array}{l}\text { Dibutuhkan kelembagaan yang mengelola secara terpadu demi keberlanjutan kawasan dari segi penyediaan rute } \\
\text { wisata yang harus ada, lalu akses yang menjangkau seluruh kawasan pecinan kembang jepun. Pengelolaan dan } \\
\text { keterpaduan dari berbagai macam variabel untuk meningkatkan kawasan pecinan }\end{array}$ \\
\hline 7. & $\begin{array}{l}\text { Moda transportasi } \\
\text { umum }\end{array}$ & $\begin{array}{l}\text { Perlu adanya angkutan yang tersedia bagi pengunjung untuk mengeliling kawasan pecinan. Contohnya becak yang } \\
\text { dapat digunakan untuk mengeliling kawasan pecinan }\end{array}$ \\
\hline 8. & Rute & $\begin{array}{l}\text { Perlu adanya bentuk rute yang informatif yang dberikan ke pengunjung bisa diakses secara fisik dan media social } \\
\text { sebagai ajang promosi kawasan pecinan. }\end{array}$ \\
\hline 9. & Pedestrian ways & Penyediaan pedestrian ways mencakup seluruh kawsan pecinan untuk keterjangakauan antar objek wisata \\
\hline 10. & Lahan Parkir & Penyediaan lahan parkir bagi wisatawan yang berkunjung kekawasan pecinan kembang jepun Kota Surabaya. \\
\hline 11. & Kuliner & $\begin{array}{l}\text { Penyediaan sentra kuliner khas kawasan pecinan yang bisa digabung dengan kawasan lain seperti kawasan arab yang } \\
\text { selalu ramai akan pengunjung bisa menjadi ajang promosi kawasan pecinan dari makanan khas secara kawasan } \\
\text { pecinan masi kurangnya bentuk promosi }\end{array}$ \\
\hline 12. & $\begin{array}{l}\text { Peluang bagi } \\
\text { mayarakat lokal }\end{array}$ & $\begin{array}{l}\text { Pembentukan kelompok sadar wisata dan nantinya aka nada pelatihan khusus untuk pemanfaatan kawasan wisata } \\
\text { pecinan }\end{array}$ \\
\hline 13 & Kemitraan & $\begin{array}{l}\text { Pembentukan kesepakatan kemitraan antar kelompok masyarakat lokal, komunitas dengan swasta dan pemerintahan } \\
\text { untuk pemasaran kawasan secara terpadu }\end{array}$ \\
\hline \multirow[t]{2}{*}{14} & $\begin{array}{l}\text { Pengelolaan cagar } \\
\text { budaya }\end{array}$ & $\begin{array}{l}\text { Pembentukan kelompok sadar wisata yang dilatih secara pengetahuan untuk melestarikan dan memanfaatkan potensi } \\
\text { yang ada. }\end{array}$ \\
\hline & & Pembentukan badan pengelola kawasan kota lama yang menaung beberapa distrik termasuk kawasan pecinan \\
\hline
\end{tabular}

didominasi non-halal yang mengakibatkan sedikt pilihan makanan apabila wisatawan muslim berkunjung kekawasan pecinan.

\section{3) Peluang bagi masyrakat lokal}

Untuk hal ini masih belum terbentuknya masyarakat/ kelompok sadar wisata. Dari hasil analisis tersebut didapati bahwa Masyarakat seharusnya membentuk kelompok sadar wisata guna membantu melestarikan kawasan pecnan itu sendiri namun dikarenakan perumahan yang cukup sedikit mengakibatkan kurangnya sumber daya manusia yang menggerakan bakan untuk membentuk kelompok tersebut. Kesadaran masyarakat yang masih rendah.

B. Menentukan Faktor yang meningkatkan daya tarik pariwisata di Kawasan Pecinan Kembang Jepun Surabaya

Untuk menentukan faktor-faktor yang meningkatkan daya tarik pariwisata kawasan pecinan Kembang Jepun Kota Surabaya dilakukan analisa Delphi yang menggabungkan beberapa pendapat dari stakeholder untuk ditarik kesimpulan.

Dalam hasil dari analisis ini tercapainya konsensus di iterasi kedua yang dimana awalnya terdapat tiga belas (13) variabel lalu ditahap consensus berkurang satu (1) variabel dan adanya tambahan dari responden sebanyak dua variabel (2) yang menjadikan terdapat empat belas (14) variabel yang mencapai consensus.
Berikut kesimpulan yang digabungkan dari beberapa pendapat stakeholders yang telah mendapat sebaran kuisioner delphi:

1) Gapura

Setelah melihat dari hasil kuisioner delphi yang di sebarkan pada responden, dapat ditarik kesimpulan bahwa variabel ini sangat berpengaruh. bentuk gapura kya kya yang sangat mewakilkan kawasan pecinan Kota Surabaya dengan gaya arsitektur orientalnya. Kawasan heritage yang berada saling berdekatan menjadi salah satu faktor pentingnya kondisi gapura sebagai penanda landmark kawasan Pecinan Kembang Jepun Kota Surabaya.

2) Bangunan Bersejarah

Melihat hasil kuisioner yang telah diberikan kepada responden dapat disimpulkan bahwa bangunan bersejarah merupakan variabel penting untuk meningkatkan nilai daya tarik kawasan pecinan. Selain arsitekturalnya namun juga terdapat nilai historis didalam setiap bangunan bersejarah menjadi nilai lebih kawasan pecinan kembang jepun Kota Surabaya.

\section{3) Tempat Sembahyang (klenteng)}

Berdasarkan pendapat dari para responden didapati kesimpulan bahwa klenteng merupakan variabel yang meningkatkan daya tarik pariwisata di kawasan pecinan Kembang jepun. corak khas kawasan pecinan yang berarsitektural oriental khas kawasan pecinan. Sejarah 


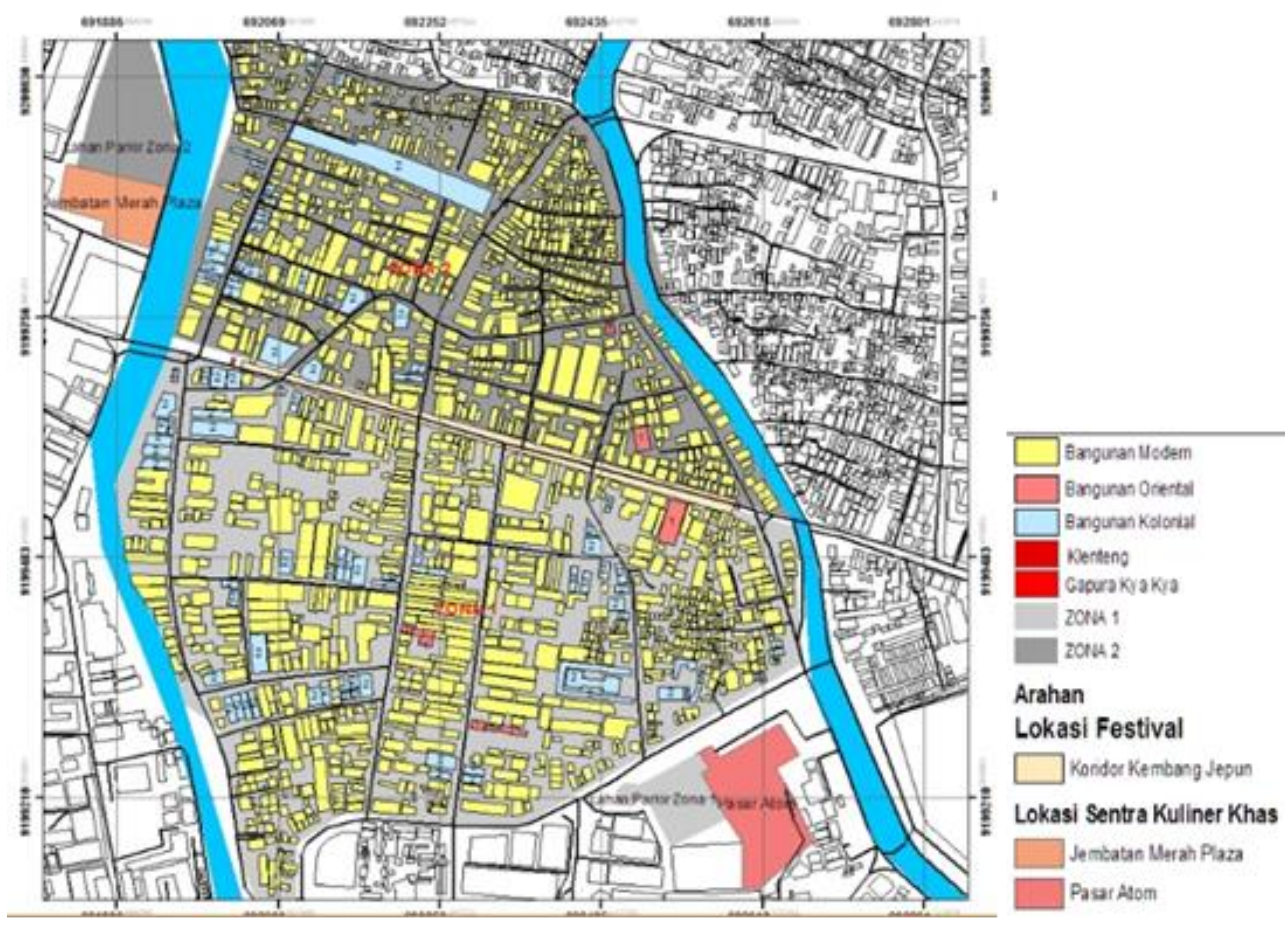

Gambar 1. Peta Arahan Daya Tarik Wisata 1

kleteng yang sudah lama ini merupakan salah satu yang perlu ditingkatkan kembali sebagai ciri khas kawasan pecinan.

\section{4) Kebudayaan perayaan imlek}

Apabila dilihat dari berbagai macam pendapat responden dapat disimpulkan bahwa harus dipertahankan karena merupakan warisan etnis tionghoa dan juga sebagai salah satu branding kawasan pecinan yang khas sekali. didalam variabel ini menjelaskan bahwa pentingnya adanya sebuah perayaan yang merepresentasikan kawasan pecinan. Dimana perayaan imlek setahun sekali dalam kalender etnis tionghoa yang bisa menjadi sebuah warisan yang bisa dimanfaatkan untuk meningkatkan niali kawasan pecinan kembang jepun.

\section{5) Festival}

Dapat disimpulkan dari tiap tiap responden setuju dengan adanya festival sebagai kegiatan rutin yang dilaksanakan oleh pihak terkait sebagai sarana branding kawasan pecinan. Variabel ini menjelaskan bahwa perlunya event yang menjadi kegiatan rutin sebagai salah satu daya tarik wisatawan untuk berkunjung ke kawasan pecinan Kembang jepun kota Surabaya

\section{6) Jaringan jalan}

Dapat dilihat dari hasil kuisioner didapati bahwa seluruh responden menyatakan setuju bahwa jaringan jalan perlu adanya pengembangan lebih untuk mendukung sektor pariwisata dan penyediaan infrastruktur bagi wisatawan. Variabel ini dapat disimpulkan mempengaruhi peningkatan daya tarik pariwisata kawasan pecinan. pada variabel ini menjelaskan bahwa diperlukan keterjangkauan antar destinasi agar mempermudah wisatawan dalam menuju ddan menikmati destinasi wisata yang ditawarkan di kawasan pecinan ini

\section{7) Moda Transportasi Umum}

Berdasarkan dari hasil kuisioner didapati kesimpulan tiap responden setuju moda transportasi umum mempengaruhi peningkatan daya tarik wisata kawasan pecinan kembang jepun Surabaya. Variabel ini menjelaskan bahwa diperlukannya kendaraan umum sebagai bantuan akses wisatawan untuk menjangkau kawasan pecinan maupun menjangkau tiap tiap destinasi dikawasan pecinan

8) Rute

Berdasarkan dari hasil kuisioner, seluruh responden telah setuju dengan variabel tersebut bahwa perlu adanya rute wisata sebagai sarana mepermudah lalu menngkatkan niali kawasan dari tiap tiap destinasi yang disajikan dalam bentuk peta wisata. variabel ini menjelaskan perlu adanya rute sebagai alat mempermudah akses dari tiap tiap lokasi yang akan dituju oleh wisatawan yang seharusnya disajikan dalam bentuk peta wisata. Oleh karena itu cenderung wisatwan secara acak menikmati kawasan pecinan

\section{9) Jalur Pejalan Kaki}

Berdasarkan dari hasil kusioner Delphi, responden semua setuju apabila variabel ini mempengaruhi peningkatan daya tarik wisata di kawasan pecinan kembang jepun. Karena wisatawan akan lebih nyaman berjalan kaki untuk menikmati kawasan pecinan dibutuhkan pedestrian ways yang memadai dari kawasan pecinan. variabel ini menjelaskan bahwa wisatawan dalam menikmati kawasan pecinan memiliki ketersediaan pilihan dalam mencapai tiap tiap objek dan destinasi wisata. Penunjang wisatawan dalam menikmati kawasan dengan berjalan kaki

\section{0) Lahan Parki}

Berdasarkan dari hasil tanggapan kusioner didapati responden semua setuju. Bahwa penyediaan parkiran perlu diperhatikan karena penting adanya untuk mendukung kegiatan pariwisata di kawasan pecinan kota Surabaya. Variabel ini menjelaskan bahwa ketersediaan lahan parkir perlu diperhatiakan karena dalam menjangkau kawasan pecinan ini yang berada di Utara Kota Surabaya perlu kendaraan yang diaman dibutuhkannya parkiran untuk kendaraan wisatawan tersebut.

\section{1) Kuliner}

Setelah melihat dari hasil kuisioner dapat disimpulkan bahwa keempat responden setuju dan variabel ini memiliki pengaruh terhadap peningkatan daya tarik pariwisata di Kawasan Pecinan Kembang Jepun Surabaya. Dalam variabel ini dijelaskan bahwa, makanan khas daerah 


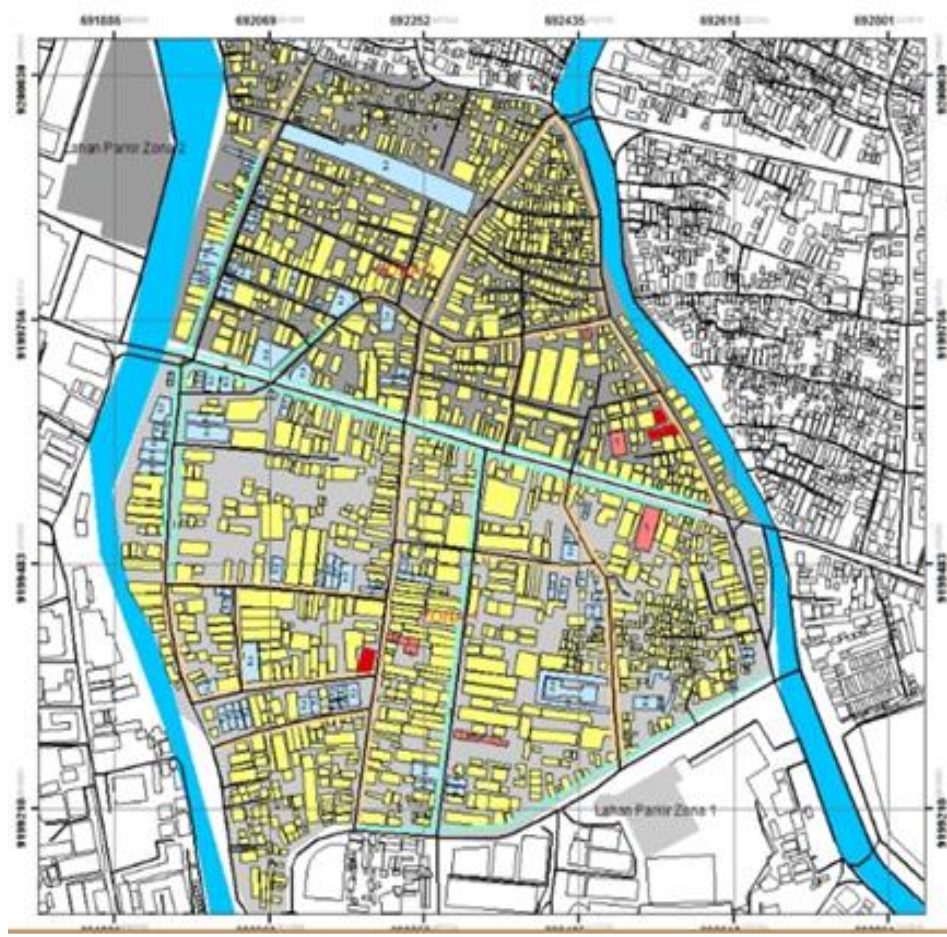

Gambar 2. Peta Arahan Daya Tarik Wisata 2

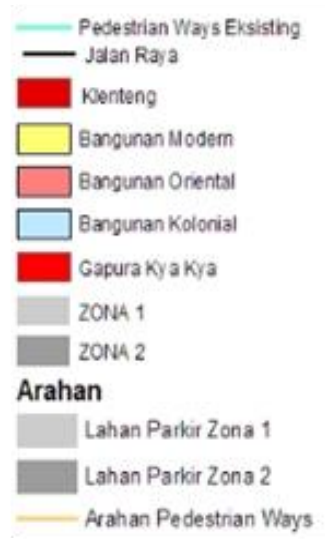

kawasan pecinan merupakan hal yang perlu ditawarkan. Makanan merupakan representasi khas kawasan cagar budaya. perlu adanya tempat khusus sentra kuliner dalam bentuk kuliner local yang berada didalam destinasi wisata pecinan

\section{2) Peluang Bagi Masyarakat Lokal}

Berdasarkan hasil dari tanggapan dari masing masing responden semua menyetujui bahwa variabel ini memiliki pengaruh sebagai penigkat daya tarik wisata apabila terstruktur pengelolaannya dengan baik. variabel ini menjelaskan bahwa pengembagan pariwisata dapat dimanfaatkan selain dalam bentuk kelompok untuk membuat cindera mata dan juga kelompok sebagai pengarah wisatawan / Tour Guide.

\section{3) Kemitraan}

Pada hasil ini ditahap II dengan penambahan variabel baru responden semuanya setuju dengan pengajuan variabel ini. Guna kemitraan sangat penting untuk menambah penyediaan dan pengadaan fasilitas pendukung kawasan wisata pecinan Kembang Jepun Kota Surabaya. Variabel ini menjelaskan bahwa perlu adanya branding kawasan yang terstruktur melalui kerjasama yang dilakukan antar pihak terkait didalam pengembangan daya tarik wisata kawasan pecinan Kembang jepun Kota Surabaya.

\section{4) Pengelolaan Cagar Budaya}

Berdasarkan kusioner Delphi yang sudah disebar didapati tanggapan dari kuisioner tersebut dalam itersi II seluruh responden menyatakan setuju terhadap penambahan variabel dan indikator baru yang mempengaruhi pengembangan destinasi demi meningkatkan daya tarik kawasan pecinan. fungsi pengelolaan akan mendukung varibel kemitraan secara langsung dan kebutuhan untuk meningkatkan potensi yang ada di kawasan tersebut. Variabel ini menjelaskan, perlunya pengelolaan kelembagaan secara terpadu yang berguna untuk keberlanjutan keberadaan objek daya tarik wisata di kawasan pecinan demi mempertahankan eksistensi antar komunitas dan lembaga terkait.

\section{Merumuskan arahan peningkatan daya tarik wisata di} kawasan pecinan Kembang Jepun Kota Surabaya

Tahap analisis terakhir dalam penelitian ini adalah merumuskan arahan penigkatan daya tarik pariwisata kawasan pecinan kota lama Surabaya. Penelitian ini mengunakan analisis deskriptif, yang langkah pertama menggabungkan faktor yang sudah disepakati disasaran kedua yaitu faktor penigkat daya tarik dan kondisi eksisting yang sudah diidentifikasi pada sasaran pertama. Langkah terakhir menggunakan best practice dikomparasikan untuk merumuskan arahan agar lebih spesifik. Tabel 3 adalah arahan peningkatan daya tarik wisata di kawasan pecinan kawasan kota lama Surabaya.

\section{KESIMPULAN/RINGKASAN}

Berdasarkan dari hasil analisis delphi yang telah dilakukan, didapatkan 14 faktor yang meningkatkan daya tarik pariwisata di kawasan pecinan Kembang Jepun Kota Surabaya . Berikut adalah faktor - faktor tersebut :

1. Gapura

2. Bangunan Bersejarah

3. Klenteng

4. Kebudayaan Perayaan Imlek

5. Festival

6. Jaringan jalan

7. Moda transportasi umum

8. Rute

9. Pedestrian Ways

10. Lahan Parkir

11. Kuliner

12. Peluang Bagi Masyarakat Lokal

13. Kemitraan

14. Pengelolaan Cagar Budaya

Dengan melihat dari 14 faktor tersebut didapatkan 16 arahan yang berdasarkan dari hasil analisis terhadap masing - masing faktor. Dari arahan tersebut diharapkan dapat 
menjadi bahan pertimbangan agar pengelolaan kawasan pecinan kembang jepun kota Surabaya dapat meningkat sesuai dengan arahan RDTRK UP Tanjung Perak, PERDA no.5 tahun 2005, dan Rencana Strategis Dinas Kebudayaan dan Pariwisata Kota Surabaya .

\section{UCAPAN TERIMA KASIH}

Penulis ingin menyampaikan terimakasih kepada Pemerintah Kota Surabaya dan Dinas terkait yang sudah memberikan data dan dukungan yang membantu penyelesaian penelitian ini.

\section{DAFTAR PUSTAKA}

[1] Rencana Detail Tata Ruang Kota (RDTRK) UP Tanjung Perak Surabaya 2011-2031

[2] PERDA Kota Surabaya No. 5 Th. 2005 tentang Pelestarian Bangunan dan/atau Lingkungan Cagar Budaya

[3] RENSTRA Dinas Kebudayaan dan Pariwisata Kota Surabaya 2016-2021

[4] H. S. Hadi, "The New Life in Old Town Surabaya Preserving the Urban Heritage through Space Revitalization,” Delft University of Technology, 2011.

[5] N. Dalkey and O. Helmer, "An experimental application of the DELPHI method to the use of experts," Manage. Sci., vol. 9, no. 3, pp. 458-467, 1963. 